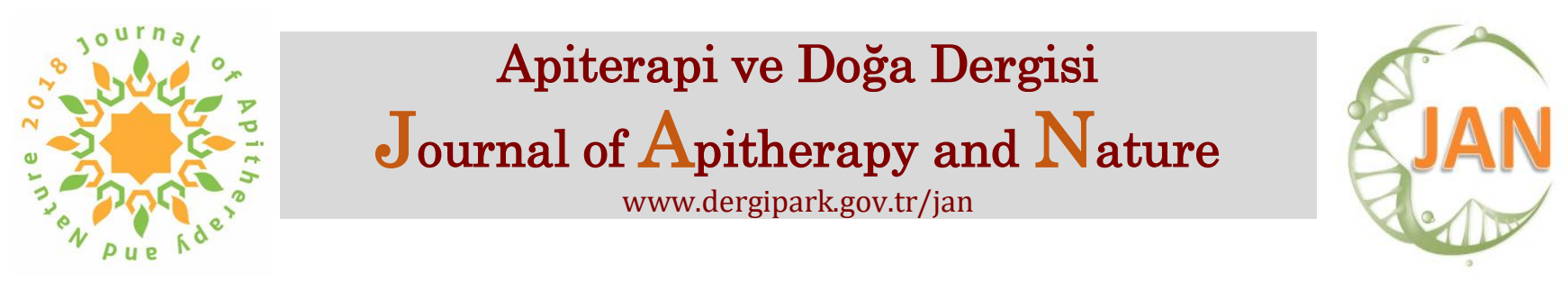

\title{
Characteristic Properties of Spurge (Euphorbia macroclada Boiss.) Honey in
}

\author{
Diyarbakır Region
}

\section{Diyarbakır Yöresinde Sütleğen (Euphorbia macroclada Boiss.) Balının Karakteristik Özellikleri}

\author{
Yakup KARA ${ }^{1}$, Ceren Didar BIRINCI ${ }^{2}$, Esra BIRINCI ${ }^{2}$, Zehra CAN ${ }^{3}$ \\ ${ }^{1}$ Department of Chemistry, Faculty of Science, Karadeniz Technical University, Trabzon, Turkey \\ yaakupkara@gmail.com, ORCID: 0000-0003-3121-5023 \\ ${ }^{2}$ Department of Pharmacy, Faculty of Health Sciences, Karadeniz Technical University, Trabzon, Turkey \\ cerendidar.birinci@gmail.com, ORCID: 0000-0002-0167-6809 \\ birinci.esra@gmail.com, ORCID: 0000-0002-0998-0661 \\ ${ }^{3}$ Department of Emergency Aid and Disaster Management, Faculty of Applied Sciences, Bayburt University, Bayburt, Turkey \\ *zehracan61@ gmail.com, ORCID: 0000-0002-7156-4941
}

Received/Geliş Tarihi: 11/06/2020, Accepted/ Kabul Tarihi: 24/08/2020

*Corresponding author/Yazışılan yazar doi:10.35206/jan.751006

e-ISSN: 2667-4734

\begin{abstract}
Spurge or euphorbia (Euphorbia macroclada Bois.), named also sütleğen or haşul is herbaceous plant species that grows widely in Turkey, but not every produces honey nectar in everywhere. Although this plant is poisonous, honey with very good taste and aroma is not toxic. It is produced from spurge flowers grown in fields left empty from lentil and chickpea harvest. The honey is harvested in August and September especially Diyarbakır and Adıyaman regions in South East Anatolia is used for many different purposes. This rather viscos honey has amber and dark amber colors and interesting flavors and taste and is not easily crystallized. In this study, some physico-chemical and antioxidant properties of spurge honey were investigated for the first time. It is one of the honeys with higher apitherapeutic value with higher Fructose / Glucose ratio (1.4-1.7) and high phenolic content (56-82 mg gallic acid (GAE/100 g) and high antioxidant capacity than flower honeys. However, further studies will reveal the true biological active value of this honey.
\end{abstract}

\section{Özet}

Sütleğen otu veya bitkisi (Euphorbia macroclada Bois.) Türkiye'de yaygın olarak yetişen otsu bir bitki tür olup, her sütleğen otu bal nektar üretmez. $\mathrm{Bu}$ bitki zehirli olmasına rağmen, çok iyi tadı ve aroması olan bal toksik değildir. Mercimek ve nohut hasatından boş kalan tarlalarda kendiliğinden yetişen sütleğen çiçeklerinden üretilmektedir. Bal Ağustos ve Eylül aylarında hasat edilir, özellikle Güneydoğu Anadolu'daki Diyarbakır ve Adıyaman bölgeleri birçok farklı amaçla kullanılmaktadır. Sütleğen nektarına göre amber renginden oldukça koyu renge kadar değişen renk ve tatlardaki bu bal, oldukça vizkoz, kolay kristalize olmayan, hafif ekşimsi bir tada ve aromaya sahiptir. Yapılan bu çalışmada ile ilk kez sütleğen balının bazı fiziko-kimyasal ve antioksidan özellikleri araştırıldı. Çiçek ballarınna göre daha yüksek Fruktoz/Glukoz oranı (1.4-1.7) ve yüksek fenolik madde miktarı (56-82 mg gallik asit (GAE/100 g) ve yüksek antioksidan kapasiteye ile apiterapötik değeri yüksek ballardan biridir. Ancak, yapılacak daha ileri çalışmalar bu balın gerçek biyolojik aktif değerini ortaya çıkaracaktır. 
Keywords: Spurge (euphorbia), honey, polyphenol, antioxidant

Abbreviations: GAE, Gallic acid equivalent

\section{INTRODUCTION}

Bee products such as honey, pollen, and propolis are natural products that are produced both for nutritional and choline health of honeybees (Baltas, Yildiz \& Kolayli, 2016). Honey is a sweet mixture of honeybees' plants that make sugar mixes from flowers and secretions by transforming them with body secretions. It is produced from two different sources as flower and honeydew. Flower honeys, on the other hand, are honey composed of flower nectars and are produced monofloral and heterofloral. Turkey is the second country of the world about honey production. Due to its geographical structure and climatic conditions, it hosts many honey plants (Kolayli, Sahin, Can, Yildiz \& Sahin, 2016; Kolayli, Can, Çakir, Okan \& Yildiz, 2018). Euphorbia or spurge honey is one of the rare unifloral honey produced and it is mostly produced in in the south-eastern Anatolia region, especially in Diyarbakır and Adiyaman province in August and September (Figure 1). The sensory properties of honey are quite different from flower heads, they have a slightly cloudy appearance, darkening color and unique aromatic properties. Since the production of spurge honey varies depending on the season, it is a honey that is not produced regularly every year. Euphorbia is a grass that grows mostly from lentil and chickpea harvest, and honey production increases in especially dry seasons. This honey, which is very
Anahtar kelimeler: Sütleğen (euphorbia), bal, polifenol, antioksidan valuable among the people of the region, uses it especially in infertility treatment, eye inflammation and wound treatments. The area of people consumes the honey mostly for infertility treatment, eye inflammation and wound treatments etc., for apitherapeutic purposes. This honey also is produced as rare honeys in Mediterranean region countries such as Lebanon, Morocco, Algeria and also rare honey (Bettar et al. 2019). In a reported case report study of spurge honey, it was reported that it was used for the treatment of wounds after surgery and that the cow recovered in a short time (Khiati et al. 2013).
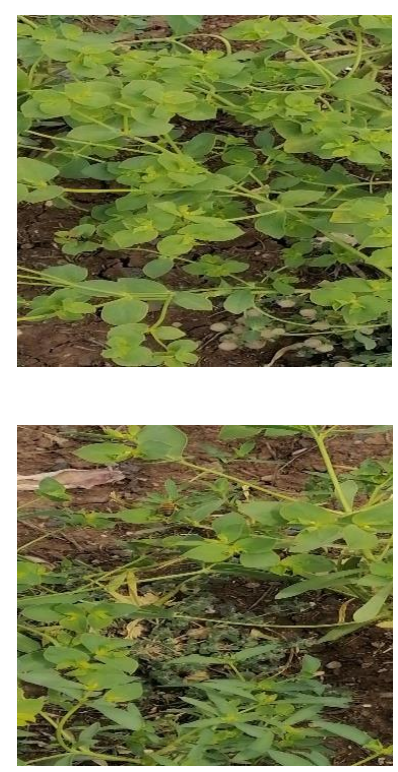

Figure 1. Euphorbia macroclada Boiss

The aim of this study was evaluated characteristics properties of Spurge honey around of the Diyarbakir and Adiyaman where produced in abundant of Turkey. 


\section{MATERIALS AND METHODS}

Ten honey samples were harvested in Diyarbakır and Adiyaman region by the experienced beekeepers (Mr. Mehmet Bayram) by Diyarbakır Beekeepers Association in August 2018. For determination of botanical origin of the honeys melissopalynological analyses were performed by microscopically (Louveaux, Maurizio \& Vorwohl, 1978). According to the counting results, the pollen rates were determined and rates were dominant pollen (45\% and more), secondary pollen (16-44\%), minor pollen (3-15\%), trace pollen (3\% and less).

\subsection{Physicochemical Properties}

Some of the physicochemical properties of moisture, optic rotation, electrical conductivity and brix of the honey samples were analyses by methods of International Honey Commission rules (IHC) (Bogdanov, Martin \& Lullmann, 2002). Proline content was measured by 201, UV-VIS spectrophotometer, USA) was determined. Sugar analysis of samples, HPLC (Elite LaChrom, Hitachi, Japan) and a reverse phase-amide column (200 /4.6 Fracture detector containing Nucleosil 100-5 $\mathrm{NH}_{2}$ ) (RID) (Can et al. 2015). Before analyzed of total phenolic amount of total antioxidant capacities of the samples honey samples were extracted. For this extraction process, $10 \mathrm{~g}$ of honey sample weighed into falcon tube $(50 \mathrm{~mL})$ room for 24 hours to prepare for analysis by adding $99 \%$ ethanol at temperature (30 mL) shaken (Heidolph Promax 2020, Schwabach,
Germany), filtered from ordinary filter paper and stored.

\subsection{Total phenolic and flavonoid content}

Total phenolic contents of the honey sample were measured by Folin Ciocalteu method (Singleton, Orthofer \& Lamuela-Raventós, 1999). Total phenolic substance is a method that includes all the polyphenols in solution such as flavonoids, stilbenes, anthocyanins, tannins etc. Gallic acid was used phenolic standard and absorbance was read at $760 \mathrm{~nm}$ and results gallic acid equivalent expressed in mg gallic acid (GAE) / 100g.

Total flavonoid substance was used according to Fukumoto and Mazza (2000). Total flavonoid amount as quercetin equivalent as mg quercetin (QE/100 g honey).

\subsection{Total Antioxidant Capacity (FRAP)}

Total antioxidant capacity of the sample was measured Ferric reducing antioxidant power assay and DPPH radical scavenging activity. The assay is based on the reduction of $\mathrm{Fe}$ (III) in the presence of an antioxidant substance in the (Fe (III) -TPTZ2,4,6-tris (2-pyridly)-S-triazin) complex (Benzie and Strain, 1996). Variable concentrations of $\mathrm{FeSO}_{4} .7 \mathrm{H}_{2} \mathrm{O}$ (from 31.25 to $1000 \mu \mathrm{M}$ ) were used as standard and blue color of product was measured at $593 \mathrm{~nm}$.

DPPH radical is a synthetic and commercially purchased radical and is used as a model. This method is based on the investigation of the change in absorbance by reducing the purple DPPH radical by an oxidizing antioxidant. The reaction is 
followed by measuring. Antioxidant activity 50\% reduction of initial DPPH concentration expressing the amounts of antioxidants spent for the $\mathrm{SC}_{50}(\mathrm{mg} / \mathrm{mL})$ (Molyneux, 2004).

\section{RESULTS AND DISCUSSION}

Physicochemical properties and melissopalynological analysis are given in Table 1. As a result of the melisopalinological analysis, it was determined that the honey has big euphoric honey and the pollen content varies between $42 \%$ and $78 \%$ (Tüylü et al., 2007). These values are an important indicator that honey is unifloral honey. The honey samples contained moisture between 16 and 16.60 and the lower moisture supplied the honey long shelf life. Electrical conductivity values were changed also narrow boarders between 0.30 and $0.32 \mathrm{mS} / \mathrm{cm}$ and the values were similar to the type of blossom honeys and were found acceptable limits of the honey codex (Can et al. 2015; Malkoç et al. 2019b). Optical rotation values of the honeys were highly negative, that indicate the samples were blossom honeys. Many studies were shown that dew honeys optical rotation is positive such as pine honey, oak honey etc. (Can et al. 2015; Serrano et al. 2019).

The mean proline value of the honey was $540 \mathrm{mg} / \mathrm{kg}$ and changed from 380 and $650 \mathrm{mg} / \mathrm{kg}$ and proline is a crucial quality parameter of honey and expresses its purity. The average proline value in spurge honeys to be higher than many honeys.

Table 1. Physicochemical analyses of Spurge honey from Diyarbakır region.

\begin{tabular}{|c|c|c|c|c|}
\hline & $\min$ & Max & mean & $\begin{array}{l}\text { Recommended (IHC / } \\
\text { http://www.ihc- } \\
\text { platform.net/publications }\end{array}$ \\
\hline \% Euphorbiaceae & 42 & 78 & 61 & - \\
\hline $\mathrm{Ph}$ & 4.20 & 4.60 & $4.36 \pm 0.30$ & \\
\hline Moisture & 15.00 & 16.60 & $16.00 \pm 0.40$ & Max.20 \\
\hline $\begin{array}{l}\text { Conductivity } \\
(\mathrm{mS} / \mathrm{cm})\end{array}$ & 0.30 & 0.33 & $0.30 \pm 0.05$ & Min.0.30 \\
\hline $\begin{array}{l}\text { Optic rotation } \\
{[\alpha]^{20}}\end{array}$ & $-3,30$ & $-4,76$ & $-3,90$ & - blossom, + dew \\
\hline HMF (mg/kg) & $\begin{array}{l}\text { Not } \\
\text { detected }\end{array}$ & 2.60 & - & $40 \mathrm{mg} / \mathrm{kg}$ \\
\hline Proline (mg/kg) & 380 & 650 & $540 \pm 39$ & Min.300 (TSE). \\
\hline Fructose $\%$ & 38.10 & 40,27 & 40,00 & Max.42 \\
\hline Glucose $\%$ & 22,30 & 25,16 & 23,20 & Min.20 \\
\hline Sucrose $\%$ & - & 3,17 & 1,56 & $\max .5$ \\
\hline Maltose \% & - & 1,50 & 0,50 & Max.4 \\
\hline
\end{tabular}

The majority of honey is made up of sugar, and honey's major sugars are fructose and glucose. The study revealed that the fructose value of spurge honey varies between $38 \%$ and $40 \%$. The glucose value varied between $22 \%$ and $25 \%$, while the mean value was found to be 23 . The average fructose / glucose ratio of 1.70 is an important indicator that honey does not crystallize easily (Can et al. 2015; Malkoç et al. 2019b). Honey with a high $\mathrm{F} / \mathrm{G}$ ratio is crystallized late. In a study was determined that $\mathrm{F} /$ G ratio as 1.46 of Jerusalem Thorn honey (Malkoç et al. 2019). The honeys with high $\mathrm{F} / \mathrm{G}$ ratio have low glycemic index values and it seems 
that the spurge honey is an ideal honey for the use of diabetic patients (Atayoglu et al. 2016). Sucrose was only detected in one honey sample of in $3 \%$. Maltose also was found only one samples at $1.5 \%$. HMF is a Maillard reaction product, responsible for the freshness of honey and whether it is subjected to heat treatment. The very low HMF value indicates that honey is raw honey, indicating a fresh honey (Turgut et al. 2018).

The agents responsible for the biological activity of honey are mostly polyphenols. The amounts of polyphenols in honey determines the color, odor, aroma and antioxidant, antimicrobial and antiinflammatory etc. properties of honey (Kara, Can \& Kolayl1, 2019; Saral, 2018). The study shows that the total amount of phenolic substance of spurge honey varies between 56 and $102 \mathrm{mg}$ GAE/100 g Table 2. There are many studies showed that the honey becomes darker as the polyphenol content increases. Chestnut honey, heather and oak honey are dark honeys, total polyphenol contents are approximately $100 \mathrm{mg}$ GAE / 100 g. In this study, the color of spurge honey was not measured, but it is a dark honey compared to flower honeys (Can et al. 2015). While the total flavonoid amount was below the determination limits, a maximum of $1.55 \mathrm{mg}$ was detected.

Total antioxidant capacity of honey was determined according to FRAP and DPPH radical scavenging activity methods. The results are given in Table 2. It was found that FRAP value ranged between 318 and $486\left(\mu \mathrm{mol} \mathrm{FeSO}_{4} \cdot 7 \mathrm{H}_{2} \mathrm{O} / 100 \mathrm{~g}\right.$ and the average value was $360 \quad(\mu \mathrm{mol}$ $\mathrm{FeSO}_{4} .7 \mathrm{H}_{2} \mathrm{O} / 100 \mathrm{~g}$.

Table 2. Antioxidant capacity of Spurge honey from Diyarbakır region.

\begin{tabular}{llll}
\hline & Min & $\max$ & Mean \\
\hline $\begin{array}{l}\text { Total phenolic content } \\
\text { (TPC) mg GA/100 g }\end{array}$ & 56 & 82 & $72 \pm 11.30$ \\
$\begin{array}{l}\text { Total flavonoid content } \\
\text { (TFC) mg QU/100 g }\end{array}$ & - & 1.55 & - \\
$\begin{array}{l}\text { Ferric reducing } \\
\text { antioxidant power }\end{array}$ & 318 & 486 & $360 \pm 56.30$ \\
$\begin{array}{l}\text { FRAP } \\
(\mu \mathrm{mol} \text { FeSO }\end{array}$.7H $\left.{ }_{2} \mathrm{O} / 100 \mathrm{~g}\right)$ & & & \\
$\begin{array}{l}\text { DPPH radical scavenging } \\
\text { activity }\left(\mathrm{mg}_{\mathrm{m}} \mathrm{ml}\right)\end{array}$ & 28 & 32 & $30.20 \pm 3.60$ \\
\hline
\end{tabular}

Comparing FRAP values with other flowers and secretion honeys in the literature, it was found remarkable with the high antioxidant capacity of spurge honey (Can et al. 2015; Malkoç et al. 2019a). As a result of the radical scavenging activity measured in terms of the amount of honey that scavenge or neutralizes $50 \%$ of the DPPH radical, the honey is a good radical cleaning agent. The low value here always reflects the ability to clean the high DPPH radical. The best activity was $28 \mathrm{mg} / \mathrm{mL}$, while the lowest was $32 \mathrm{mg} / \mathrm{mL}$ in the spurge honeys. When compared these values with the data in the literature, it was found that acacia honey was $150 \mathrm{mg} / \mathrm{mL}$ (Can et al. 2015) Anzer honey (49 mg /mL), mutliflower honey (98 $\mathrm{mg} / \mathrm{mL}$ ) (Saral, 2018).

\section{CONCLUSION}

As a result, spurge honey is a honey with high phenolic content, sugar composition and high fructose ratio, especially antidiabetic potential, but it is necessary to investigate the phenolic 
composition and other biological properties of honey.

Acknowledgments: We are thanks to Diyarbakır Beekepers Union (Fahri Saylak and Mehmet Bayram) who are supplied the honey samples for investigations. Also, thanks to Prof. Dr. Sevgi KOLAYLI for encouraging this research.

\section{REFERENCES}

Atayoğlu, A.T., Soylu, M., Silici, S. \& Inanc, N. (2016) Glycemic index values of monofloral Turkish honeys and the effect of their consumption on glucose metabolism. Turkish J. Med. Scie., 46(2),483-488.

https://doi.org/10.3906/sag1502102

Baltas, N., Yildiz, O., \& Kolayli, S. (2016) Inhibition properties of propolis extracts to some clinically important enzymes. J. Enzyme Inhib. Med. $\quad$ Chem., 31(sup1), 52-55. https://doi.org/10.3109/14756366.2016.1167049

Benzie, I. F., \& Strain, J. J. (1996) The ferric reducing ability of plasma (FRAP) as a measure of "antioxidant power": the FRAP assay. Anal. Biochem., 239(1), 70-76.

Bettar, I., González-Miret, M.L., Hernanz, D., Marconi, A., Heredia, F. J., \& Terrab, A. (2019) Characterisation of Moroccan Spurge (Euphorbia) honeys by their physicochemical characteristics, mineral contents and colour. Arabian J. Chem., 12(8),2052-2060,

https://doi.org/10.1016/j.arabjc.2015.01.003

Bogdanov, S., Martin, P., \& Lullmann, C. (2002) Harmonised methods of the international honey commission. Swiss Bee Res. Centre, FAM, Liebefeld.

Can, Z., Yildiz, O., Sahin, H., Akyuz Turumtay, E., Silici, S., \& Kolayli, S. (2015) An investigation of Turkish honeys: their physico-chemical properties, antioxidant capacities and phenolic profiles. Food Chem., 180, 133-141. https://doi.org/10.1016/j.foodchem. 2015.02.024
Fukumoto, L. R., \& Mazza, G. (2000) Assessing antioxidant and prooxidant activities of phenolic compounds. J. Agric. Food Chem., 48(8), 3597 3604. https://doi.org/10.1021/jf000220w

Kara, Y., Can, Z., \& Kolaylı, S. (2019) HPLC analyses of polyphenolic compounds in oak (Querces frainetto) honey from Kirklareli region of Turkey. Turkish J. Anal. Chem., 1.

Khiati, B., Bacha, S., Ahmed, M., Aissat, S., Meslem, A., \& Djebli, N. (2013) Wound care with euphorbia honey after nucleation: A case report. Clinical Microbial., $2,129$. https://doi.org/10.4172/2327-5073.1000129

Kolayli, S., Sahin, H., Can, Z., Yildiz, O., \& Sahin, K. (2016) Honey shows potent inhibitory activity against the bovine testes hyaluronidase. J. Enzyme Inhib. Med. Chem., 31(4), 599-602. https://10.3109/14756366.2015.1054819

Kolayli, S., Can, Z., Çakir, H. E., Okan, O. T., \& Yildiz, O. (2018) An investigation on Trakya region Oak (Quercus spp.) honeys of Turkey: Their physico-chemical, antioxidant and phenolic compounds properties. Turkish

Biochem., 43(4), $J$. https://doi.org/10.1515/tjb-2017-0174

Louveaux, J., Maurizio, A., \& Vorwohl, G. (1978) Methods of melissopalynology. Bee world, 59(4), 139-157.

Malkoç, M., Çakır, H., Kara, Y., Can, Z., \& Kolayl1, S. (2019a) Phenolic composition and antıoxidant properties of anzer honey from Black Sea Region of Turkey. Uludag Bee J., 19(2). https://doi.org/10.31467/uluaricilik.602906

Malkoç, M., Kara, Y., Özkök, A., Ertürk, Ö., \& Kolaylı, S. (2019b) Karaçalı (Paliurus SpinaChristi Mill.) Balının Karakteristik Özellikleri. Uludag Bee J., 19(1). https://doi.org/10.31467/uluaricilik.535658

Molyneux, P. (2004) The use of the stable free radical diphenylpicrylhydrazyl (DPPH) for estimating antioxidant activity. Songklanakarin $J$. Scie. Technol., 26(2), 211-219. 
Saral, Ö. (2018) Determination of antioxidant activities of the chestnut and flower honeys collected from Eastern Black Sea Region in Turkey. Apiterapi ve Doğa Dergisi, 1(1), 28-32.

Singleton, V. L., Orthofer, R., \& LamuelaRaventós, R. M. (1999) Analysis of total phenols and other oxidation substrates and antioxidants by means of folin-ciocalteu reagent. In Methods in enzymol., (Vol. 299, pp. 152-178). Academic press.

https://doi.org/10.1016/S0076-6879(99)99017-1
Turkut, G. M., Degirmenci, A., Yildiz, O., Can, Z., Cavrar, S., Karahalil, F. Y., \& Kolayli, S. (2018). Investigating 5-hydroxymethylfurfural formation kinetic and antioxidant activity in heat treated honey from different floral sources. J. Food Meas. Charact., 12(4), 2358-2365. https://doi.org/10.1007/s11694-018-9852-y

Tüylü, Ö., A., \& Sorkun, K. (2007). The invesigation of morphologic analysis of pollen grains which are economically important and collected by Apis mellifera L. Hacettepe $J$. Biochem. Chem., 35, 31-38 